\title{
PENGARUH PEMBELAJARAN KEWIRAUSAHAAN DAN MOTIVASI TERHADAP MINAT UNTUK BERWIRAUSAHA MAHASISWA IKIP PGRI JEMBER
}

\author{
Roro Aditya Novi Wardhani ${ }^{1)}$, Suci Rachmawati ${ }^{2}$ \\ Program Studi Pendidikan Ekonomi, IKIP PGRI Jember \\ dhee251110@gmail.com
}

\begin{abstract}
This Research was conducted to analyze and know whether there is an effect of the enter reneurship learning and enterpreneurial motivation on the enter reneurial interest of IKIP PGRI Jember students partially and simulta. This type of research was quantitative research. Primary data was collected thought questionnaires distributedto the students of IKIP PGRI Jember Economic education department at 2016 and 2017 academic year. The population of this research was 121 students. The sample of thisresearch was 40 respondents of the economic education department at 2016 and 2017 academic year. Hypothesis test used multiple linier regression analysis. Based on the results of the data analysis used t-test or partially that is between enterpreneurship learning obtained tcount $(2,482)>$ ttable $(2,021)$ with a significance of 0,018 so that there is an influence on student enterpreneurship interest. t-test data analysis or partially that is between enterpreneurial motivation obtained tcount $(2,093)<$ ttable $(2,021)$ with a significance of 2,093 so that there is an influence on student enterpreneurship interest. from the data analysis used f-test of simultareonly that is between enterpreneurship learning and enterpreneurial motivation.
\end{abstract}

Keywords: Entrepreneurship Learning, Entrepreneurial Motivation, Interest in entrepreneurship.

\begin{abstract}
Abstrak
Penelitian ini ditujukan untuk menganalisis dan mengetahui adakah pengaruh dari pembelajaran kewirausahaan dan motivasi terhadap minat untuk berwirausaha pada mahasiswa IKIP PGRI Jember secara parsial dan simulta. Jenis penelitian ini merupakan penelitian kuantitatif. Data primer dikumpulkan melalui kuesioner yang kemudian disebarkan pada mahasiswa Prodi Pendidikan Ekonomi IKIP PGRI Jember Tahun angkatan 2016 dan 2017. Populasi dalam penelitian ini berjumlah 121 mahasiswa dan jumlah sampel adalah 40 responden mahasiswa prodi pendidikan ekonomi tahun angkatan 2016 dan 2017. Pengujian hipotesis menggunakan analisis regresi linear berganda. Berdasarkan hasil analisis data menggunakan uji t atau secara parsial yaitu antara pembelajaran kewirausahaan didapat nilai thitung $(2,482)>$ thabel $(2,021)$ dengan signifikansi 0,018 sehingga ada pengaruh terhadap minat untuk berwirausaha mahasiswa. analisis data uji t atau secara parsial yaitu antara Motivasi Berwirausaha didapat nilai thitung $(2,093)>$ ttabel $(2,021)$ dengan signifikansi 0,043 sehingga ada pengaruh terhadap minat untuk berwirausaha mahasiswa. Dari analisis data menggunakan uji $\mathrm{f}$ atau secara simultan yaitu antara pembelajaran kewirausahaan dan motivasi berwirausaha didapat nilai fhitung $(8,073)>\mathrm{f}$ tabel $(3,25)$ berpengaruh terhadap prestasi belajar siswa dengan signifikansi 0,001 sehingga ada pengaruh terhadap minat berwirausaha mahasiswa.
\end{abstract}

Kata Kunci: Pembelajaran Kewirausahaan, Motivasi Berwirausahaan, Minat untuk berwirausaha. 


\section{PENDAHULUAN}

Perguruan tinggi saat ini pada umumnya telah memiliki wadah yang bisa digunakan mahasiswa sebagai ajang untuk melatih diri serta mengembangkan ide-ide kreatifnya, sehingga kini pembelajaran kewirausahaan tidak hanya mengajarkan apa yang ada di teori saja, tetapi kini lebih ditekankan pada Praktik-praktik kewirausahaan. Praktik yang dilakukan oleh mahasiswa memerlukan bimbingan dari dosen pengampu mata kuliah yang bersangkutan, bimbingan yang dilakukan oleh dosen digunakan untuk mengawasi dan mengevaluasi serta menilai kinerja para mahasiswa saat melakukan praktik kewirausahaan. Mahasiswa yang menempuh mata kuliah kewirausahaan akan memiliki mental dan motivasi yang tinggi untuk berwirausaha sehingga akan meningkatkan minat serta kecintaan mereka terhadap dunia kewirausahaan (Aprilianty, 2012). Tingginya minat untuk berwirausaha akan melahirkan wirausaha muda yang memiliki visi yang jelas di masa depan. Mereka akan menjadi lebih mandiri, kreatif dan inovatif dalam menciptaan peluang bisnis dan penemuanpenemuan baru. Motivasi berwirausaha sangat penting dalam menumbuhkan minat untuk berwirausaha karena walaupun seseorang berminat pada sesuatu jika tidak ada motivasinya untuk melakukan hal tersebut juga akan sia-sia (Hazraini, 2017).

Menurut (Tria, 2017), pembelajaran kewirausahaan merupakan upaya yang sengaja dilakukan oleh seorang pendidik untuk membelajarkan peserta didik tentang kewirausahaan, agar mereka mengetahui kiat-kiat kewirausahaan dengan baik, sehingga dapat meningkatkan kompetensi pengetahuan dan keterampilan yang diperlukan untuk menciptakan suatu peluang usaha. jadi kesimpulannya adalah pembelajaran kewirausahaan merupakan upaya agar peserta didik dapat meningkatkan pengetahuan dan keterampilan untuk membuat sebuat peluang usaha.

Hazraini (2017) mengemukakan bahwa motivasi kewirausahaan merupakan faktor pendorong seseorang untuk menciptakan sesuatu yang baru dan berbeda dengan yang lain atau dari yang sudah pernah ada dengan cara yang sekreatif dan inovatif mungkin tidak meniru hasil karya seseorang. Kesimpulan dari teori di atas adalah motivasi berwirausaha merupakan pendorong seseorang agar dapat menciptakan seseuatu yang kreatif dan inovatif.

Yahya dan Kristina (2015) menjelaskan bahwa minat untuk berwirausaha merupakan keinginan yang dimiliki untuk bekerja keras atau berkemauan keras untuk berusaha memenuhi kebutuhan hidupnya dan menjalankan usahanya tanpa rasa takut dengan risiko dan senantiasa belajar dari kegagalan yang dialami. Maka kesimpulannya adalah minat untuk berwirausaha merupakan keinginan bekerja keras untuk mencapai keberhasilan.

Penelitian terdahulu yang melakukan penelitian serupa, terdiri dari Adetia (2017), menemukan bahwa sikap dan motivasi berwirausaha memiliki pengaruh terhadap minat untuk berwirausaha pada anggota komunitas bisnis IIBF regional Lampung. Firdaus (2017), juga menemukan bahwa pendidikan kewirausahaan dan motivasi secara simultan berpengaruh terhadap minat untuk berwirausaha. Tanjung (2017) menemukan bahwa secara simultan pembelajaran kewirausahaan dan motivasi kewirausahaaan berpengaruh positif signifikan terhadap minat menjadi pengusaha muda (young entrepreneur) pada mahasiswa program studi Manajemen Fakultas Ekonomi dan Bisnis USU. Hasil penelitian juga menunjukkan bahwa secara parsial, pembelajaran kewirausahaan dan motivasi kewirausahaaan berpengaruh positif signifikan terhadap minat menjadi pengusaha 
muda (young entrepreneur) pada mahasiswa program studi Manajemen Fakultas Ekonomi dan Bisnis USU.

Kegiatan untuk mendukung visi dan misi IKIP PGRI Jember menjadi perguruan tinggi yang bermutu, berdaya saing, dan mandiri, maka sejumlah kegiatan kemahasiswaan digelar di IKIP PGRI Jember. Salah satunya adalah seminar nasional kewirausahaan yang digelar pada hari Sabtu 13 Januari 2018. Melalui seminar tersebut mahasiswa diajak untuk mengeluarkan segenap kreativitas mereka yang bernilai ekonomis unruk diterapkan saat ini juga. Hal itu dirasa mampu melatih generasi muda berwirausaha dan membentuk mahasiswa yang mandiri, kreatif dan inovatif.

Program studi Pendidikan Ekonomi Tahun ajaran 2017-2018 IKIP PGRI Jember ikut berpartisipasi dalam seminar dan bazar yang diselenggarakan oleh IKIP PGRI jember, tetapi dalam acara tersebut mahasiswa lebih tertarik untuk mengikuti seminar dari pada bazar karena dalam seminar tersebut mahasiswa tidak diminta biaya (gratis) tetapi mahasiswa yang mengikuti seminar tersebut diminta untuk membeli produk yang di dijual distand bazar tersebut. setelah peneliti survey ternyata mereka hanya ingin mendapatkan nilai untuk memenuhi syarat kelulusan mata kuliah kewirausahaan saja. Peserta bazar sangat antusias dengan adanya bazar tersebut, karena dengan adanya bazar mereka memiliki motivasi untuk mengeluarkan produk-produk yang membuat konsumen tertarik tetapi terdapat sedikit pemaksaan agar mahasiswa yang mengikuti kegiatan tersebut berminat membeli produk yang di jual pada bazar. Sehingga dapat disimpulkan bahwa minat meraka untuk berwirausaha setelah lulus kuliah nantinya masih belum terlihat.

Berdasarkan pada uraian di atas maka tujuan penelitian ini adalah untuk menganilisa dan mengetahui:
1. pengaruh pembelajaran kewirausahaan secara parsial signifikan terhadap minat untuk berwirausaha mahasiswa IKIP PGRI Jember.

2. pengaruh motivasi berwirausaha secara parsial signifikan terhadap minat untuk berwirausaha mahasiswa IKIP PGRI Jember.

3. pengaruh pembelajaran kewirausahaan dan motivasi berwirausaha secara simultan terhadap minat untuk berwirausaha mahasiswa IKIP PGRI Jember.

\section{METODE PENELITIAN}

Penelitian ini menggunakan metode kuantitatif, yaitu metode yang digunakan untuk menguji teori tertentu dengan cara meneliti hubungan antar variabel. Sedangkan teknik pengambilan sampelnya menggunakan metode Purposive sampling. Jumlah sampel dalam penelitian ini adalah sebanyak 40 mahasiswa prodi pendidikan ekonomi tahun ajaran 2017/2018 IKIP PGRI Jember. Penulis menggunakan teknis analisis regresi linier berganda dengan objek penelitian 40 mahasiswa dilanjutkan Uji t dan Uji f untuk memudahkan menganalisis data atau menguji hipotesis.

$$
\mathrm{Y}=\mathrm{bO}+\mathrm{b} 1 \mathrm{X}_{1}+\mathrm{b} 2 \mathrm{X}_{2}+\mathrm{ei}
$$

Dimana :

$\mathrm{Y}=$ Minat untuk berwirausaha

$\mathrm{bO}=$ Konstanta

$\mathrm{b}_{1}, \mathrm{~b}_{2}=$ Koefisien tiap-tiap variabel

$\mathrm{X}_{1}=$ pembelajaran kewirausahaan

$\mathrm{X}_{2}=$ motivasi berwirausaha

$\mathrm{e} \quad=$ error

Uji F

Dilakukan untuk mengetahui pengaruh secara simultan dari pembelajaran kewirausahaan dan motivasi berwirausaha terhadap minat mahasiswa untuk berwirausaha. Dasar untuk pengambilan keputusannya adalah jika nilai sig $<\alpha=5 \%$. 
Ujit

Digunakan peneliti untuk menguji pengaruh secara parsial antara masingmasing variabel pembelajaran kewirausahaan dan motivasi berwirausaha terhadap minat untuk berwirausaha. Dasar untuk memutuskan bahwa ada pengaruh parsial adalah jika nilai sig $<=5 \%$.

\section{HASIL DAN PEMBAHASAN \\ Hasil}

Setelah hasil uji instrumen dinyatakan valid dan relibel, maka selanjutnya dilakukan Analisis Regresi linier berganda dilakukan untuk menguji pengaruh pembelajaran kewirausahaan dan motivasi berwirausaha terhadap minat untuk berwirausaha mahasiswa. Hasil Uji Regresi Linier Berganda dapat dilihat pada Tabel 1.

Tabel 1. Rekapitulasi Regresi Linier Berganda

\begin{tabular}{lcrcc}
\hline \multicolumn{1}{c}{ Variabel } & $\mathrm{t}_{\text {hitung }}$ & $\mathrm{T}_{\text {tabel }}$ & Sig. & Keterangan \\
\hline (Constant) & & & & \\
Pembelajaran Kewirausahaan & 2,482 & 2,021 & 0,018 & Signifikan \\
Motivasi Berwirausaha & 2,093 & 2,021 & 0,043 & Signifikan \\
$\quad F_{\text {hitung }}$ & $=8,073$ & & & $=3,25$ \\
$\quad$ Sign. F & $=0,001$ & $\mathrm{~F}_{\text {tabel }}$ & & \\
\hline
\end{tabular}

\section{Hasil Uji F}

Hasil uji $\mathrm{F}$, didapat nilai $\mathrm{F}_{\text {hitung }}=8,073$ dengan sig. 0,001. Nilai $F_{\text {hitung }}>$ dari $F_{\text {tabel }}$ $(8,073>3,25)$ dan nilai sig. $0,001<0,05$, hasil penelitian menunjukkan jika secara simultan ada pengaruh yang signifikan dari variabel pembelajaran kewirausahaan dan motivasi berwirausaha secara simultan terhadap minat untuk berwirausaha.

\section{Hasil Uji t}

1) Nilai $t_{\text {hitung }}$ variabel pembelajaran kewirausahaan $>t_{\text {tabel }}(2,482 \geq 2,021)$ maka $\mathrm{H}_{0}$ ditolak dan $\mathrm{H}_{1}$ diterima, ini menunjukkan jika variabel pembelajaran kewirausahaan $\left(\mathrm{X}_{1}\right)$ berpengaruh positif signifikan terhadap variabel minat untuk berwirausaha $(\mathrm{Y})$.

2) Nilai $t_{\text {hitung }}$ variabel motivasi berwirausaha $>t_{\text {tabel }}(2,093 \geq 2,021)$ maka $\mathrm{H}_{0}$ ditolak dan $\mathrm{H}_{2}$ diterima, ini menunjukkan jika variabel motivasi berwirausaha $\left(\mathrm{X}_{2}\right)$ berpengaruh positif signifikan terhadap variabel minat untuk berwirausaha (Y).

\section{Pembahasan}

Hasil analisis regresi yang diperoleh menjelaskan bahwa variabel pembelajaran kewirausahaan berpengaruh secara signifikan terhadap minat berwirausaha mahasisiwa prodi pendidikan ekonomi tahun angkatan 2017 dan 2016 IKIP PGRI Jember, ini dibuktikan dengan perhitungan regresi dengan tingkat signifikansi 0,018. Berpengaruhnya pembelajaran kewirausahaan terhadap minat berwirausaha mahasiswa mengindikasikan bahwa mahasiswa memahami materi kewirausahaan yang diberikan oleh dosen mata kuliah kewirausahaan dengan baik. Hasil penelitian hipotesis pertama atau $\mathrm{H} 1$ yang menyatakan bahwa pembelajaran kewirausahaan berpengaruh signifikan terhadap minat berwirausaha mahasiswa diterima. Penelitian ini tidak sejalan dengan penelitian sebelumnya yang dilakukan oleh Tria Adetia (2017), Dalam penelitian yang dilakukan oleh tria adetia, bahwa pendidikan kewirausahaan 
tidak terdapat pengaruh yang signifikan terhadap minat berwirausaha pada anggota komunitas IIBF Regional Lampung.

Hasil analisis regresi diperoleh bahwa variabel Motivasi berwirausaha berpengaruh secara signifikan terhadap Minat berwirausaha mahasiswa prodi pendidikan ekonomi tahun angkatan 2017 dan 2016 IKIP PGRI Jember, ini dibuktikan dengan perhitungan regresi dengan tingkat signifikansi 0,043. Berpengaruhnya Motivasi berwirausaha terhadap Minat berwirausaha mengindikasikan bahwa mahasiswa ingin memiliki usaha sendiri agar mereka tidak diatur oleh orang lain. Hasil penelitian hipotesis kedua atau $\mathrm{H} 2$ yang diajukan yaitu bahwa Motivasi berwirausaha berpengaruh signifikan terhadap Minat berwirausaha mahasiswa diterima. Penelitian ini tidak sejalan dengan penelitian sebelumnya yang dilakukan oleh Vera Firdaus (2017). Dalam penelitian yang dilakukan oleh Vera Firdaus, Motivasi berprestasi tidak ada pengaruh terhadap minat berwirausaha mahasiswa fakultas ilmu pendidikan IKIP PGRI Jember.

Hasil analisis regresi diperoleh bahwa variabel pembelajaran kewirausahaan dan motivasi berwirausaha berpengaruh secara signifikan terhadap minat berwirausaha, ini dibuktikan dengan perhitungan regresi dengan tingkat signifikansi 0,001. Berpengaruhnya pembelajaran kewirausahaan dan motivasi berwirausaha terhadap minat berwirausaha mahasiswa mengerti pembelajaran kewirausahaan dan berminat untuk berwirausaha. Hasil penelitian hipotesis ketiga $\mathrm{H} 3$ yang menyatakan bahwa pembelajaran kewirausahaan dan motivasi berwirausaha berpengaruh signifikan terhadap minat berwirausaha mahasiswa. Penelitian ini sejalan dengan penelitian sebelumnya yang dilakukan oleh Hazraini Tanjung 2017. Dalam penelitian yang dilakukan Hazraini Tanjung, menunjukkan bahwa secara simultan, pengaruh pem- belajaran kewirausahaan dan motivasi kewirausahaaan berpengaruh positif dan signifikan terhadap minat menjadi pengusaha muda (young entrepreneur) pada mahasiswa program studi Manajemen Fakultas Ekonomi dan Bisnis USU.

\section{PENUTUP \\ Simpulan}

Berdasarkan hasil penelitian dan uraian-uraian yang sudah dijelaskan pada pembahasan sebelumnya, maka dapat diambil kesimpulan sebagai jawaban atas permasalahan yang diaujukan pada penelitian ini, yaitu :

a. Penelitian yang dilakukan secara parsial menunjukkan bahwa variabel bebas yaitu pembelajaran kewirausahaan berpengaruh signifikan terhadap Minat untuk berwirausaha mahasiswa prodi ekonomi IKIP PGRI Jember.

b. Motivasi berwirausaha berpengaruh signifikan terhadap Minat berwirausaha mahasiswa prodi ekonomi IKIP PGRI Jember.

c. Pembelajaran kewirausahaa dan motivasi berwirausaha berpengaruh signifikan terhadap Minat untuk berwirausaha mahasiswa IKIP PGRI Jember.

\section{Saran}

Saran yang akan menjadi implikasi bagi penelitian selanjutnya, antara lain:

a. Diharap agar dosen mata kuliah kewirausahaan dapat menambah program tentang praktik kewirausahaan dan studi banding di beberapa home industry agar mahasiswa menambah kreatifitas dan semakin termotivasi untuk berwirausaha.

b. Dalam penelitian ini pasti banyak kekurangan, karena itu Peneliti selanjutnya dapat melakukan penelitian dengan judul yang sama diharapkan mampu mempebaharui indikator dan memakai acuan yang berbeda 


\section{DAFTAR PUSTAKA}

Aprilianty, E. (2012). Pengaruh Kepribadian Wirausaha, pengetahuan Kewirausahaan dan Lingkungan Terhadap Minat untuk berwirausaha Siswa SMK. Jurnal Pendidikan Vokasi, Vol2, Nomor 3.

Vera, Firdaus. 2017. "Pengaruh Pendidikan Kewirausahaan Dan Motivasi Berprestasi Terhadap Minat untuk berwirausaha Mahasiswa Fakultas Ilmu Pendidikan IKIP PGRI Jember (The Influence Of Entrepreneurship Education And Achievement Motivation To Entrepreneurship Interest In IKIP PGRI Jember Students)" Volume 14, Nomor 2.

Sugiyono. (2015). Metode Penelitian Pendidikan: Pendekatan Kuantitatif, Kualitatif, dan R\&D. Bandung: Alfabeta.

Sugiyono. (2016). Metode Penelitian Pendidikan: Pendekatan Kuantitatif, Kualitatif, dan R\&D. Bandung: Alfabeta.
Tanjung Hazraini. (2017). Pengaruh Pembelajaran Kewirausahaan Dan Motivasi Kewirausahaan Terhadap Minat Menjadi Pengusaha Muda (Young Enterpreneur) Pada Mahasiswa Program Studi Manajemen Fakultas Ekonomi Dan Bisnis Usu. http://repositori.usu.ac.id/handle/1234 $\underline{56789 / 1032}$.

Tria. Adetia. (2017). Pengaruh Pembelajaran Kewirausahaan, Sikap, Dan Motivasi Berwirausaha Terhadap Minat Berwirausaha (Studi Pada Anggota Komunitas Bisnis Indonesian Islamic Business Forum Regional Lampung) http://digilib.unila.ac.id/29708/3/SKRI PSI\%20TANPA\%20BAB\%20PEMB AHASAN.pdf

Uswaturrasul, Yahya dan Kristina Sisilia. (2015). "Analisis Minat Dan Motivasi Berwirausaha Mahasiswa (Studi Pada Program Studi Administrasi Bisnis Telkom University Angkatan 2011) Analysis Of Student's Entrepreneurial Intention And Entrepreneurial Motivation (A Study On Business Administration Study Program. Telkom University. Class Of 2011)" Vol.2. No.3 Hal 3588. 